\title{
Evaluasi Kinerja Wirausahawan Etnik China Lulusan SMK di Kota Singkawang Kalimantan Barat
}

\author{
Ahmadi \\ STKIP PGRI Pontianak
}

\begin{abstract}
Abstrak: Tujuan dari penelitian ini adalah untuk memperoleh pemahaman yang mendalam dan komprehensif tentang kinerja kewirausahaan dari etnik China lulusan SMK di Kota Singkawang, Kalimantan Barat. Evaluasi kinerja dilakukan melalui pengukuran karakteristik kewirausahaan dari para lulusan yang diambil secara purposif dengan menggunakan pedoman wawancara dan pedoman observasi yang dipersiapkan khusus untuk penelitian ini. Dengan menggunakan analisis data model interaksi dari Miles dan Hubermans melalui kegiatan reduksi data, penyajian dan verifikasi dan penarikan simpulan maka diperoleh hasil evaluasi kinerja yang terandalkan. Hasil penelitian menunjukkan bahwa kewirausahaan mereka dibentuk melalui kurikulum sekolah, pembentukan kebiasaan, Agama Khonghucu dan kultur, sejarah dan tekanan hidup yang dialami oleh etnik China Hakka di Singkawang. Setiap keluarga etnik China memiliki usaha, usaha tersebut dipimpin oleh ayah. Ayah sebagai kepala keluarga, memimpin pemujaan kepada roh leluhur sekaligus memimpin bisnis dibantu seluruh anggota keluarga tanpa kecuali anak-anaknya yang masih kanak-kanak. Kinerja Kewirausahaan merupakan sinergi dari kehidupan keluarga, kurikulum sekolah, kultur China dan kehidupan dengan orang lain di masyarakat.
\end{abstract}

Kata kunci: entrepreneurship, China Hakka, Khonghucu, dan evaluasi kinerja

\begin{abstract}
This study aims at obtaining in-depth and comprehensive understanding of the entrepreneurship performance of Chinese ethnic Vocational Secondary School graduates in Singkawang of West Kalimantan. Evaluation on performance was carried out by measuring entrepreneurship characteristics of the graduates who were selected purposively as subjects of the study. A qualitative approach was implemented through In-depth interviews and specially designed participant observation guide were used to collect data. The obtained data was the analyzed by means of Miles and Hubermans Interaction Analysis Model for which data reduction, presentation and verification were conducted. The findings indicate that entrepreneurship performance of the subjects was shaped by the school curriculum, habit formation, the Khonghucu religion, as well as culture, history and living pressure experienced by the Hakka Chinese ethnic group in Singkawang. It is obvious that every Chinese family owns a business, which is led by the father as head of family, leader in worshipping their ancestor spirits, as well as the leader in operating their business with support of the whole family members except the young children. Entrepreneurship performance becomes a synergy of family life, school curriculum, Chinese culture, and social interaction with other people in the society.
\end{abstract}

Key words: entrepreneurship, China Hakka, Khonghucu, performance evaluation.

\section{Pendahuluan}

Indonesia merupakan negara yang terdiri dari pulau-pulau, baik besar maupun kecil dalam jumlah yang mencapai 17.002 buah pulau. Dari jumlah tersebut baru sekitar 6.041 buah pulau yang sudah memiliki nama. Selebihnya belum memiliki nama bahkan belum teridentifikasi. Salah satu pulau yang merupakan pulau terbesar di Indonesia adalah pulau Kalimantan atau dulu disebut pulau Borneo dengan luas sekitar 539.460 km2. Sebagian dari pulau ini yakni Kalimantan bagian utara termasuk wilayah negara Malaysia dan negara Brunei Darussalam. Karena luasnya pulau Kalimantan maka banyak pula ragam suku bangsa yang mendiami pulau tersebut. Di samping penduduk asli yang mendiami tersebut terdapat pula pendatang baik yang berasal dari antar pulau di Indonesia maupun dari negara lain, seperti misalnya dari negeri China.

Apabila kita berkunjung ke Singkawang salah satu dari 14 Kabupaten/Kota di Provinsi Kalimantan Barat, kita akan menemukan etnik 
China yang kehidupannya sangat berbeda dibanding etnik China lain di Indonesia. Kehidupan etnik ini ada kemiripannya dengan etnik China yang ada di Sarawak Malaysia maupun kehidupan orang China yang ada di Singapura.

Menurut Lontaan (1975:247) sejarahnya dahulu etnik China Singkawang datang secara berangsur-angsur sejak abad ke-8. Sebagian lagi didatangkan oleh raja-raja Sambas dan Mempawah pada sekitar abad ke-17 sebagai tenaga kerja di tambang emas yang banyak terdapat di daerah Monterado dan Mandor yang keduanya merupakan bagian dari kerajaankerajaan tersebut, bahkan juga menyebar ke Bangka Belitung. Di kedua daerah tersebut, pada waktu itu etnik China tidak berdagang seperti pada umumnya mereka melainkan bekerja sebagai kuli.

Ciri kesamaan dengan daerah lain ditandai dengan banyaknya ditemukan klenteng-klenteng atau pekong (tempat sembahyang orang-orang China), yayasan kematian, rumah abu, loya atau dukun serta budaya asing China lainnya seperti barongsay, liong (naga) maupun penggunaan bahasa Khek dari orang Hakka yang mereka gunakan sebagai alat komunikasi sehari-hari di lingkungan keluarga dan masyarakat.

Pada masa Orde Baru kebebasan dalam menjalankan hak-hak individu bagi orang-orang China ini sangat dibatasi. Hak-hak individu yang dibatasi tersebut misalnya dalam melaksanakan agama sesuai dengan ajaran Konghucu, menyelenggarakan perayaan agama, mengatur pendidikan dan memperoleh pekerjaan sebagai pegawai negeri. Instruksi Presiden Republik Indonesia Nomor 14, Tahun 1967 tentang pengaturan bagi warga negara keturunan China melarang warga negara keturunan China ini melakukan/menyelenggarakan kegiatan pesta kegiatan keagamaan dan kegiatan lain yang sejenis secara terbuka. Peraturan tidak membenarkan apabila perayaan keagamaan yang berafiliasi kultural dengan negeri leluhur dilaksanakan di tempat umum melainkan hanya dibenarkan apabila dilaksanakan di dalam lingkungan keluarga saja.

Pada masa pemerintahan Presiden Abdurrahman Wahid Instruksi Presiden Nomor 14, Tahun 1967 tentang pengaturan bagi warga negara Republik Indonesia keturunan China dihapus. Dengan penghapusan Inpres Nomor 14 itu maka kedudukan etnik China ini dianggap sama dengan etnik atau suku-suku yang lain di Indonesia. Dampak dari penghapusan Instruksi Presiden Nomor 14, Tahun 1967 tersebut maka perayaan Imlek, Cap Go Meh dan perayaan lain yang bercorak budaya dan keyakinan yang telah turun temurun dilakukan khususnya oleh etnik keturunan China di Kalimantan Barat dapat dinikmati kembali oleh penduduk Kalimantan Barat. Bahkan, wisatawan manca negara banyak yang berdatangan ke Singkawang di antaranya wisatawan dari Malaysia, Hongkong, Taiwan dan dari negara-negara lain yang secara khusus ingin menyaksikan perayaan yang sarat mengandung budaya China itu. Perayaan-perayaan ini memiliki daya tarik yang kuat bagi etnik China yang telah lama bermukim di luar negeri. Perayaan-perayaan semacam ini sebenarnya dapat juga disaksikan di Singapura, namun para wisatawan manca negara lebih tertarik pada keasliannya. Perayaan Imlek, Cap Go Meh dan perayaan lain yang berlangsung di Singkawang menurut para wisatawan lebih unik dan spesifik karena melibatkan ratusan orang thatung atau orang yang menunjukkan kekebalan tubuhnya dengan cara menusukkan benda tajam ke bagian tubuhnya dan loya dan tidak ada lagi di negeri asalnya.

Dampak lain dari penghapusan Inpres Nomor 14, Tahun 1967 itu kegiatan keagamaan di kota yang dikenal dengan sebutan "Kota Seribu Kelenteng" tersebut, Singkawang semakin marak. Demikian juga kegiatan pendidikan bagi etnik ini berjalan dengan lancar tanpa mengalami kendala sehingga etnik China merasakan kebebasan dalam kehidupannya.

Daerah pesisir yang membentang dari kota Pontianak ke sebelah utara hingga kota Singkawang yang berjarak kurang lebih 145 kilometer memiliki populasi penduduk etnik China yang cukup besar. Bahkan, kota Singkawang yang merupakan pusat pemerintahan kota memiliki penduduk etnik China sebanyak hampir 60 persen dari total penduduknya yang berjumlah 175.983 jiwa (2006). Dari jumlah tersebut jumlah wanitanya hampir mencapai 49 persen dari sekitar 105.589 jiwa penduduk keturunan China yang ada, sehingga kota Singkawang lebih dikenal 
dengan "kota amoi" suatu sebutan bagi gadisgadis China, karena semua sektor pekerjaan terwakili oleh amoi-amoi ini. Mereka terlibat dalam semua lini pekerjaan dari pekerjaan yang kasar hingga yang halus serta pekerjaan lainnya yang tidak lazim dikerjakan oleh gadis-gadis China seperti layaknya di kota-kota besar lain di Indonesia.

Penduduk keturunan China di Singkawang tidak hanya mencari nafkah di bidang perdagangan maupun jasa sebagaimana penduduk keturunan China di Jawa, akan tetapi jumlah mereka yang mencari nafkah di bidang pertanian, penangkapan ikan, buruh kecil dan sebagainya juga cukup besar. Hal ini melanjutkan tradisi leluhur mereka yang di Kalimantan Barat ini mencari nafkah dari bekerja sebagai petani, buruh, nelayan dan sebagainya sejak zaman kerajaan-kerajaan dahulu.

Dari segi ekonomi, orang-orang etnik China ini dibagi dalam dua kategori. Pertama, bagi yang tinggal di daerah perkotaan, berstatus sosial ekonomi menengah ke atas. Hal ini dikarenakan mereka mempunyai modal dan keberanian untuk melakukan perdagangan di pusat kota. Usaha perdagangan ini sangat menjanjikan sehingga banyak yang berhasil dan dapat menyekolahkan anaknya ke luar kota bahkan sampai ke luar negeri. Kedua, bagi yang tinggal di daerah pedesaan/pedalaman standar sosial ekonominya masih rendah bahkan memprihatinkan. Mereka tergolong ekonomi menengah ke bawah dan bahkan ada yang hidup di bawah garis kemiskinan. Pekerjaan mereka di daerah pedesaan antara lain bertani, nelayan, buruh bangunan, pengrajin keramik, penjual makanan dan minuman di sekolah-sekolah, di pinggir jalan dan bahkan ada pula yang menjadi pengemis.

Kaum wanitanya ada juga yang menekuni pekerjaan kasar seperti pekerjaan laki-laki bahkan melebihi laki-laki. Kemiskinan juga menjadi kenyataan yang dihadapi oleh penduduk keturunan China yang mencari nafkah dengan berbagai jalan. Salah satu cara mengatasi kemiskinan serta untuk mengangkat derajat kehidupan keluarga, di antara warga keturunan China ini tidak segan-segan untuk menikahkan anak gadisnya dengan orang-orang etnik dari Taiwan yang sering datang ke daerah ini untuk mencari jodoh. Menurut orang dari Taiwan, pada umumnya karakteristik amoi dari Singkawang adalah pandai mengurus suami, tidak terlalu mementingkan kebendaan, dan sanggup hidup sederhana.

Perhatian warga keturunan China terhadap pendidikan pada umumnya cukup besar, sekalipun di antara mereka kehidupannya sulit. Para remajanya pada umumnya sekolah sambil membantu orang tua, baik dalam melakukan perdagangan, pertanian maupun kerajinan, atau bekerja dengan orang lain untuk memperoleh penghasilan guna meringankan beban orang tua dalam pembiayaan sekolahnya. Keadaan ini terlihat pada mereka, baik yang tinggal di daerah perkotaan maupun yang berada di pedesaan.

Latar belakang budaya dan kehidupan etnik China di daerah pesisir Kalimantan Barat ini sangat berpengaruh terhadap pendidikan bagi anakanaknya. Mereka tidak segan-segan menyekolahkan anaknya walaupun tidak mampu membiayai. Anak-anaknya tidak canggung sekolah meski harus membawa jajanan untuk dijual, atau mereka bersepeda sambil memboncengkan keranjang dagangan orang, untuk mendapat sekedar upah. Hal ini sangat jarang terjadi di daerah lain. Motivasi untuk memperoleh pendidikan bagi orang China sangat tinggi, terbukti dari besarnya persentase jumlah siswa yang masuk sekolah dari etnik ini. Seluruh anggota keluarga terlibat dalam mendukung anak-anak mereka yang sekolah agar dapat sekolah dan berhasil. Terlihat dalam keluarga selain orang tua yang bekerja juga kakak beradik ikut mendukung, hal ini banyak dijumpai kakak bekerja membanting tulang seperti misal mendorong gerobak, berjualan, demi membiayai adiknya sekolah.

Kondisi yang demikian membentuk pribadi yang tangguh dalam berusaha pada keluarga etnik China di daerah ini khususnya di Singkawang, baik mereka yang terdidik maupun yang tidak terdidik. Etnik China sudah dibiasakan dan dilatih bekerja keras untuk dapat hidup mandiri, dalam menggapai keberhasilan hidup.

Sejalan dengan keinginan kuat dari warga keturunan China agar anak-anak mereka memperoleh pendidikan yang dapat dijadikan bekal untuk kehidupan kelak maka tidak mengherankan bilamana di daerah-daerah 
dimana warga keturunan China ini bermukim, terdapat sekolah-sekolah yang pada umumnya dikelola oleh yayasan-yayasan atau badan-badan penyelenggara pendidikan China, antara lain Chen Chiang, Chung Hua Tsung Hui dsb. Sekolahsekolah ini menyelenggarakan kegiatan pembelajaran dengan menggunakan bahasa China, dan hampir semuanya merupakan Sekolah Dasar. Bila anak-anak warga keturunan China ini akan melanjutkan pendidikan mereka ke jenjang yang lebih tinggi maka mereka masuk ke sekolahsekolah yang pada umumnya diselenggarakan oleh yayasan pendidikan yang berazaskan agama Kristen Katolik maupun Protestan. Sekolahsekolah ini, seperti SMP Bruder dan SMP Suster di Singkawang; SMP Amkur di Pemangkat (sebuah kota kecamatan $31 \mathrm{~km}$ ke arah utara kota Singkawang) sebagian besar siswanya adalah anak-anak warga keturunan China. Namun, peristiwa G.30 S. serta pergolakan yang timbul sesudahnya di daerah ini, ialah pergolakan PGRSPARAKU; telah mendorong pemerintah pada waktu itu bertindak keras terhadap badan-badan penyelenggara pendidikan seperti Chen Chiang, Chung Hua Tsung Hui, BAPERKI dsb. Dengan ditutupnya sekolah-sekolah tersebut, maka warga keturunan China mengarahkan perhatian mereka kepada sekolah-sekolah yang diselenggarakan oleh yayasan-yayasan pendidikan yang berazaskan agama Kristen Katolik maupun Protestan.

Keputusan Panglima Kodam XII Tanjungpura selaku Pelaksana Kopkamtib Daerah Kalimantan Barat tertanggal 25 Desember 1971 Nomor 231/ KAMDA/XII/1971 tentang Pembaharuan di Bidang Pendidikan yang mengharuskan dilaksanakannya pembauran antara warga keturunan China dan warga pribumi waktu itu di sekolah-sekolah dengan perbandingan siswa 50:50 telah mendorong anak-anak warga keturunan China masuk sekolah-sekolah negeri. Sementara itu, pendidikan tingkat menengah atas mulai banyak didirikan di Singkawang maupun juga di Pontianak sejalan makin banyaknya anak-anak warga keturunan China yang telah tamat Sekolah Menengah Pertama dan ingin terus melanjutkan sekolahnya.

Salah satu jenis sekolah menengah yang merupakan pilihan sebagian besar anak-anak warga keturunan China adalah SMK, dalam hal ini pada waktu itu adalah SMEA (Sekolah Menengah
Ekonomi tingkat Atas). Pilihan ini tidak berlebihan, karena di SMEA diajarkan pengetahuan dan keahlian yang cocok dengan minat dan kebutuhan warga keturunan China yang banyak bergerak di bidang perdagangan. Tidaklah mengherankan bahwa di Singkawang dan sekitarnya pertumbuhan SMEA (yang kini menjadi SMK dengan bidang keahlian Bisnis dan Manajemen) cukup pesat, baik yang diselenggarakan pemerintah, maupun badan-badan penyelenggara pendidikan swasta.

Perimbangan jumlah siswa etnik China dan etnik yang lain di SMK Negeri berbanding 70 dengan 30 artinya, siswa SMK Negeri di kota Singkawang 70 persen berlatar belakang etnik China dan selebihnya 30 persen siswa non China. Di SMK mereka memperoleh mata pelajaran Kewirausahaan dan mata pelajaran yang lain sejak dari kelas I hingga kelas III meliputi tiga kelompok pengajaran yakni Kelompok Normatif, Kelompok Adaptif dan Kelompok Produktif.

Pemilihan program yang dikembangkan oleh SMK juga sangat mempengaruhi animo masuk sekolah. SMK yang mengembangkan program yang menarik minat siswa dari etnik China misalnya sekolah yang mengembangkan Program Produktif bahasa Mandarin ternyata memperoleh siswa dalam jumlah yang lebih besar dibanding sekolah yang tidak mengembangkan program itu.

Materi yang diajarkankan kepada siswa-siswa etnik China dengan etnik yang lain sama. Kegiatan dan perlakuan yang diberikan kepada siswa pun sama, namun hasil atau produknya nanti setelah tamat sangat berbeda. Tamatan SMK yang berasal dari etnik China sangat berbeda terutama dari kewirausahaannya. Etnik China yang sudah lulus ternyata banyak yang berani berwirausaha dan berhasil dalam usahanya sementara dari etnik yang lain sedikit sekali yang mencoba berwirausaha. Kalaupun ada yang berwirausaha, jumlahnya sangat kecil dan kebanyakan mereka gagal dalam berusaha.

Kondisi yang demikian menarik sekali untuk diketahui sehingga penelitian ini difokuskan untuk menemukan berbagai informasi secara faktual, mendalam dan holistik melalui evaluasi kinerja wirausahawan etnik China lulusan SMK. Penelitian tersebut diarahkan untuk mengevaluasi karakteristik wirausahawan Iulusan SMK khusus dari 
etnik China di kota Singkawang.

Di samping itu melalui penelitian ini akan diungkap pula faktor-faktor apa yang mempengaruhi kinerja kewirausahaan etnik China Iulusan SMK di kota Singkawang, Provinsi Kalimantan Barat.

Berdasarkan identifikasi tersebut di atas maka permasalahan yang diangkat secara umum dalam penelitian evaluasi ini adalah Bagaimana kinerja wirausahawan etnik China lulusan SMK di Kota Singkawang Provinsi Kalimantan Barat?

Permasalahan umum tersebut kemudian dirinci dan dirumuskan sebagai berikut: 1) Bagaimanakah karakteristik wirausahawan etnik China lulusan SMK di kota Singkawang Provinsi Kalimantan Barat; 2) Faktor-faktor apa yang mempengaruhi kinerja wirausahawan etnik China Iulusan SMK di kota Singkawang Kalimantan Barat? 3) Mengapa peran pendidikan yang diterima di SMK lebih mendukung dalam membentuk kinerja wirausahawan etnik China Iulusan SMK di kota Singkawang Provinsi Kalimantan Barat? 4) Apakah kewirausahaan etnik China lulusan SMK lebih mendukung dibanding dengan yang bukan lulusan SMK? Dan 5) Apakah yang menonjol dari kewirausahaan etnik China lulusan SMK di kota Singkawang, Kalimantan Barat?

Penelitian evaluasi ini secara umum bertujuan untuk memperoleh pemahaman yang mendalam dan holistik mengenai kinerja kewirausahaan etnik China lulusan SMK di kota Singkawang, Provinsi Kalimantan Barat. Penelitian evaluasi ini juga bertujuan untuk mengevaluasi faktor-faktor apa yang mempengaruhi kinerja kewirausahaan etnik China lulusan SMK.

Tujuan penelitian evaluasi ini secara khusus dirumuskan sebagai berikut: 1) Untuk mengetahui bagaimana karakteristik wirausahawan etnik China alumni SMK Singkawang, 2) Untuk mendapatkan informasi tentang faktor-faktor yang mempengaruhi kinerja kewirausahaan etnik China Iulusan SMK di kota Singkawang, 3) Untuk memperoleh gambaran yang jelas "mengapa" peran pendidikan di sekolah lebih mendukung pembentukan kinerja kewirausahaan etnik China lulusan SMK, 4) Untuk memperoleh pemahaman mengenai perbedaan antara kinerja wirausahawan lulusan SMK dengan wirausahawan
nonSMK, dan 5) Untuk mendapatkan informasi yang faktual dan objektif mengenai karakteristik yang menonjol dari kewirausahaan etnik China lulusan SMK di kota Singkawang.

\section{Kajian Literatur Pengertian Evaluasi}

Evaluasi dalam suatu kegiatan pendidikan memiliki peran yang penting. Melalui aktivitas evaluasi akan diperoleh data yang dibutuhkan untuk mengetahui sampai sejauh mana keberhasilan suatu kegiatan atau program. Menurut Gronlund (1985:2), evaluasi berasal dari bahasa Inggris dari kata Evaluation yang berarti suatu proses yang sistematik untuk menentukan atau membuat keputusan, sampai sejauh mana suatu tujuan atau program telah tercapai.

Evaluasi dapat diartikan sebagai proses menilai sesuatu berdasarkan kriteria atau tujuan yang telah ditetapkan, yang selanjutnya diikuti dengan pengambilan keputusan atas obyek yang dievaluasi. Sebagai contoh, evaluasi proyek, kriterianya adalah tujuan dari pembangunan proyek tersebut, apakah tercapai atau tidak, apakah sesuai dengan rencana atau tidak, jika tidak mengapa terjadi demikian dan langkahlangkah apa yang perlu ditempuh selanjutnya. Hasil dari kegiatan penilaian atau evaluasi adalah bersifat kualitatif (Djaali, 2000:2).

Stufflebeam mendefinisikan istilah evaluasi sebagai suatu proses penggambaran, pencarian dan pemberian informasi yang sangat berguna bagi pengambil keputusan dalam menentukan alternatif keputusan. Definisi lain yang mirip dengan itu dikemukakan oleh Trespeces yang mengatakan bahwa evaluasi adalah proses penggambaran, pencarian dan pemberian informasi yang sangat bermanfaat bagi pengambil keputusan dalam menentukan keputusan yang akan diambil (Badrun 1995:2)

Untuk mengetahui tercapai atau tidaknya suatu tujuan evaluasi memerlukan ukuran baku atau kriteria yang harus ditetapkan lebih dahulu. Di samping istilah evaluasi dan penilaian terdapat juga istilah yang hampir sama bahkan mendekati kesamaan yakni Assessment. Istilah asesmen yang berasal dari Bahasa Inggris Assessment berarti menilai sesuatu. Menilai itu sendiri berarti mengambil keputusan terhadap sesuatu dengan 
mengacu pada ukuran tertentu misalnya menilai baik buruk, sehat atau sakit, pandai atau bodoh, dan sebagainya. Jadi, antara penilaian dengan evaluasi hampir memiliki pengertian yang sama. Bedanya adalah pada evaluasi akan berakhir dengan pengambilan keputusan, sedangkan pada penilaian hanya sebatas memberikan nilai saja.

Berbagai pendapat tersebut dapat disarikan bahwa evaluasi pada dasarnya adalah proses untuk menilai berdasarkan data yang dikumpulkan dengan menggunakan kriteria atau tolok ukur tertentu.

\section{Evaluasi Kinerja}

Istilah kinerja atau prestasi kerja merupakan terjemahan dari kata "performance" dari bahasa Inggris. Kinerja atau performance diartikan sebagai tingkat pencapaian hasil atau pelaksanaan tugas tertentu. Kinerja atau performance juga diartikan sebagai ungkapan kemampuan yang didasari oleh pengetahuan, sikap dan keterampilan serta motivasi dalam menghasilkan sesuatu. Kinerja individu atau kinerja setiap orang dipengaruhi oleh berbagai faktor yakni antara lain faktor kompetensi individu orang yang bersangkutan.

Menurut Simanjuntak (2005:103), kompetensi individu adalah kemampuan atau keterampilan seseorang dalam melakukan kerja atau melaksanakan pekerjaan yang menjadi tanggung jawabnya. Kompetensi individu dipengaruhi oleh 2 faktor, yakni a) kemampuan dan keterampilan kerja dan b) motivasi dan etos kerja. Evaluasi kinerja sering disebut dengan istilah "performance-evaluation" atau "performance appriasal". Appriasal berasal dari bahasa Latin "apparatiare" yang diartikan sebagai pemberian nilai atau harga. Dengan demikian, evaluasi kinerja berarti memberikan penilaian terhadap kinerja seseorang dengan menggunakan standar yang telah ditetapkan sebelumnya.

Setiap kegiatan suatu mengarah pada pencapaian tujuan. Untuk memperoleh informasi tentang pencapaian tujuan tersebut dapat ditempuh melalui berbagai kegiatan yang dapat menentukan sampai sejauh mana tujuan tersebut dapat dicapai. Usaha yang ditempuh untuk memperoleh informasi tersebut dinamai evaluasi. Evaluasi pada penulisan ini dibatasi evaluasi dalam kegiatan penelitian Penelitian evaluasi ini bertujuan untuk mengungkap kualitas kinerja di bidang kewirausahaan.

\section{Evaluasi Kinerja Kewirausahaan Pengertian Entrepreneurship}

Entrepreneur menurut Benedicta (2003: 21) berasal dari kata entrepredre dari bahasa Perancis yang diartikan sebagai undertake yang berarti menjalankan, melakukan, berusaha. Juga dapat diartikan sebagai to set about atau memulai. selain itu dapat diartikan to attempt yang berarti mencoba atau berusaha.

Entrepreneurship sering diistilahkan dengan kewiraswastaan atau kewirausahaan. Ketiga istilah tersebut banyak dipergunakan secara luas dalam kehidupan sehari-hari dan dianggap relatif sama meskipun ada perbedaan. Perbedaan tersebut terletak pada titik beratnya, istilah entrepreneurship dan istilah kewirausahaan lebih dititikberatkan pada bidang bisnis atau perdagangan sedangkan istilah kewiraswastaan titik beratnya adalah pada bidang yang lain. Dalam penggunaannya ketiga istilah tersebut orang cenderung menyamakan sesuai dengan keperluan pemakainya.

Menurut Wasti Soemanto (1984: 42) istilah wirausaha sama dengan istilah wiraswasta, berasal dari kata "wira - swa - sta". Wira berarti berani, luhur, teladan. Swa berarti sendiri, dan sta artinya berdiri. Wiraswasta berarti: "gagah berani berdiri sendiri sebagai teladan yang luhur "Dari ungkapan etimologi itu maka wiraswasta berarti keberanian, keutamaan dan keperkasaan dalam memenuhi kebutuhan serta memecahkan permasalahan hidup dengan kekuatan yang ada pada diri sendiri.

Geoffrey G. Meredith (1996:42) mengartikan kewirausahaan sebagai "proses untuk melakukan sesuatu yang baru (kreatif) dan mengerjakan sesuatu yang berbeda (inovatif) yang bertujuan untuk menghasilkan kekayaan untuk orang dan nilai tambah terhadap masyarakat". Kewirausahaan merupakan proses penciptaan sesuatu usaha baru yang menekankan pada kreativitas dengan menggunakan sumber daya yang ada secara konsisten. Kewirausahaan dilakukan untuk mencapai keuntungan yang maksimal bagi perusahaan. 
Dari berbagai pendapat dapat ditarik pengertian entrepreneurship atau kewirausahaan secara umum dan dapat dinyatakan sebagai berikut: Entrepreneurship adalah keberanian untuk menciptakan usaha baru dengan menekankan kreativitas dan inovasi, dengan menggunakan sumber daya yang ada, untuk memperoleh keuntungan sebanyak-banyaknya. Entrepreneurship menurut berbagai batasan tersebut tidak hanya dibatasi dengan pengertian pengusaha, atau berdagang, berbisnis melainkan juga termasuk di dalamnya penyanyi, artis, penyair atau siapa pun yang dengan keberaniannya menciptakan sesuatu yang baru, menciptakan lapangan kerja baru dengan menekankan kreativitas dan sumber daya yang ada dapat disebut sebagai entrepreneur.

\section{Karakteristik Kewirausahaan}

Secara umum seorang wirausahawan perlu memiliki karakteristik tertentu untuk berhasil dalam berwirausaha. Karakteristik adalah sifat psikis dari suatu sistem kepribadian atau personality. Wirausahawan secara umum perlu memiliki karakteristik sehingga berhasil dalam berwirausaha. Karakteristik secara garis besar adalah percaya diri. Wirausahawan juga memiliki karakter berorientasi tugas dan hasil, berani mengambil risiko, memiliki jiwa kepemimpinan, keorisinalan dan selalu berorientasi ke masa depan. Karakteristik umum tersebut dijabarkan lagi menjadi karakteristik yang bersifat khusus dan spesifik yang disebut dengan karakter atau karakteristik. Dengan karakteristik tersebut maka akan tercipta sesuatu usaha baru melalui wirausaha.

Mengacu kepada berbagai pendapat tentang karakteristik wirausahawan maka dapat disimpulkan bahwa karakteristik wirausahawan yang sesuai dengan fokus penelitian ini adalah 1 ) Karakteristik percaya diri meliputi percaya diri, keyakinan, ketidaktergantungan, individualitas dan optimis, 2) Karakter kebutuhan akan prestasi meliputi orientasi pada hasil/keuntungan, ketekunan dan ketabahan, tekat dan kerja keras, mempunyai dorongan yang kuat, enerjik dan penuh inisiatif, 3) Kemampuan mengambil risiko, ialah suka pada tantangan, 4) Berlaku sebagai pemimpin meliputi kemampuan bergaul dengan orang lain, bersedia menanggapi saran dan kritik, inovatif, 5) Fleksibel dan punya banyak sumber meliputi serba bisa dan mengetahui banyak, 6) Karakter yang lain adalah mempunyai pandangan ke depan dan perspektif ke arah kemajuan.

Untuk mengevaluasi kinerja seseorang atau individu maka karakteristik kewirausahaan ini dapat dijadikan sebagai salah satu kriteria atau tolok ukur atau pembanding dari kinerja kewirausahaan.

\section{Kewirausahaan di Sekolah Menengah Kejuruan Pembinaan Kewirausahaan}

Pembinaan kewirausahaan di sekolah merupakan bagian integral dari pendidikan pada umumnya, yakni dalam rangka pembentukan manusia Indonesia yang berkualitas. Apakah kewirausahaan dapat ditanamkan melalui pendidikan di sekolah? Ada dua pandangan yang bertolak belakang mengenai pertanyaan ini. Dua pandangan ini dikemukakan oleh Masngudi (1995:2) berikut ini, a) Kewirausahaan merupakan naluri yang dibawa sejak lahir oleh seseorang dan karenanya tidak dapat dipelajari. Paham ini menyatakan bahwa kewirausahaan hanya ada sebagai "Born Entrepreneurship" dan b) Kewirausahaan dapat dikembangkan melalui pendidikan dan pelatihan. Menurut paham ini kewirausahaan dapat dilihat sebagai "Trained Entrepreneurship".

Kurikulum sekolah, khususnya untuk Sekolah Menengah Kejuruan dalam rangka pembinaan sikap kewirausahaan perlu ada penataan. Penataan itu menyangkut isi maupun strategi pelaksanaan kurikulumnya. Komponen isi menyangkut materi pendidikan dan pelatihan, sedangkan komponen strategi menyangkut strategi pencapaian tujuan. Strategi pelaksanaan kurikulum yang dilaksanakan sekarang adalah Kurikulum Berbasis Kompetensi.

Berbicara tentang Kurikulum Berbasis Kompetensi menurut penjelasan Suparno (2002:364) dalam HAR Tilaar (2002) bahwa: Berbeda dengan masa-masa sebelumnya (19751999) di mana kurikulum disusun secara terpusat dan dituangkan secara detail dalam GBPP, sekarang kurikulum disusun dalam bentuk kompetensi. Kalau dahulu GBPP mengandung komponen TIU/TIK, Pokok Bahasan dan Sub Pokok 
Bahasan, Metode, Media serta Evaluasi, maka struktur Kurikulum Berbasis Kompetensi hanya terdiri atas Kompetensi Dasar, Materi Pokok dan Indikator Pencapaian Hasil. Bagaimana mencapai kompetensi tersebut diserahkan kepada guru dan sekolah.

Melalui penataan kurikulum dengan menerapkan Kurikulum Berbasis Kompetensi diharapkan lulusan sekolah, khususnya Sekolah Menengah Kejuruan, benar-benar memiliki kompetensi yang mendukung. Program pendidikan dan pelatihan yang dilaksanakan secara intensif dapat diciptakan bentuk budaya sekolah dan pembenahan kurikulum. Pendidikan Kejuruan di Sekolah Menengah Kejuruan akan berdampak menghasilkan peserta didik yang memiliki sikap kewirausahaan sehingga mampu menjadi wirausahawan yang berhasil. Untuk dapat memiliki kompetensi kewirausahaan, guru SMK perlu didukung dengan penguasaan sistem pembelajaran yang sesuai sehingga membekali siswa dengan berbagai pengetahuan, keterampilan dan sikap yang mendukung kewirausahaan.

Penggunaan kata sikap dalam pembentukan kewirausahaan bagi siswa karena sikap adalah suatu kecenderungan yang relatif stabil dan berlangsung terus menerus untuk bertingkah laku atau mereaksi sesuatu dengan cara tertentu. Siswa Sekolah Menengah Kejuruan dalam hal ini belum benar-benar berwirausaha dan baru belajar berwirausaha.

Dari berbagai pendapat para ahli di atas dapat ditarik simpulan bahwa kewirausahaan dapat diajarkan kepada orang lain melalui pendidikan di sekolah. Tujuan Pendidikan Nasional di Indonesia mengarah pada dimensi yang sangat mendukung pembinaan kewirausahaan. Kurikulum Sekolah Menengah Kejuruan perlu ditata sehingga mampu menghasilkan lulusan yang memiliki sikap kewirausahaan dan dapat berkembang menjadi wirausahawan yang berhasil setelah lulus dari Sekolah Menengah Kejuruan.

Penataan kurikulum mencakup juga penggunaan teori pembelajaran yang sesuai dan mendukung bagi guru dalam pembentukan sikap siswa sehingga tercipta pribadi wirausahawan yang berhasil.

\section{Kurikulum SMK Bidang Keahlian Bisnis dan Manajemen}

Kurikulum SMK yang digunakan adalah Kurikulum Nasional untuk Sekolah Menengah Kejuruan yang dirancang dan disusun secara fleksibel sehingga mampu mengantisipasi dan mengikuti perkembangan. Karena sifatnya yang fleksibel dan dinamis maka kurikulum SMK sering mengalami perubahan dan penyempurnaan. Kurikulum SMK yang berlaku saat penelitian ini berlangsung menghendaki perpaduan antara Pendekatan Pengembangan Kurikulum Berbasis Kompetensi atau (Competence Based Curriculum Development Approach) dan Pendekatan Pengembangan Kurikulum Berbasis Luas (Broad Based Curriculum Development Approach).

Dari berbagai penjelasan tersebut dapat disarikan bahwa untuk mengadakan evaluasi kinerja kewirausahaan diperlukan pemahaman yang mendalam dan holistik tentang standar yang harus dicapai sebagai norma yang harus dipenuhi oleh hasil pendidikan dan pelatihan yang telah diperoleh para lulusan. Standar kelulusan yang harus dimiliki oleh lulusan tersebut merupakan tolok ukur yang akan menjadi sasaran evaluasi dari kinerja wirausahaan yang dapat dilaksanakan melalui penelitian.

\section{Faktor-faktor yang Mempengaruhi Kewirausahaan}

Ada beberapa faktor yang berpengaruh terhadap kewirausahaan. Secara garis besar faktor tersebut dibedakan dalam faktor yang bersifat internal dan yang bersifat eksternal. Faktor internal yang berasal dari dalam diri individu meliputi: keluarga, agama atau keyakinan, kultur atau budaya yang melekat dan mewarnai kehidupan. Di samping itu, kondisi psikologis yang bersifat permanen dalam diri seseorang, dalam penelitian ini adalah kondisi tekanan hidup yang dialami. Faktor-faktor yang bersifat eksternal meliputi: lingkungan sekolah dan lingkungan masyarakat. Faktor-faktor ini baik yang bersifat internal maupun eksternal berpengaruh terhadap kewirausahaan seseorang khususnya terhadap kewirausahaan etnik China lulusan SMK di kota Singkawang Provinsi Kalimantan Barat. Berikut ini secara singkat akan diidentifikasi teori-teori yang mendukung faktor-faktor tersebut. 


\section{Kehidupan Keagamaan Etnik China}

Orang-orang China pada umumnya memiliki kepercayaan yang bersifat turun temurun dalam hal pemujaan terhadap leluhurnya. Kepercayaan orang China kepada arwah para leluhur sudah ada sejak sebelum Khonghucu lahir. Kepercayaan itu diekspresikan dalam bentuk kultus terhadap orang tua sejak masih hidup hingga yang telah meninggal dunia dalam bentuk pemujaan terhadap leluhur. Dalam pemujaan terhadap arwah para leluhur, ayah menjadi pemuka dalam pemujaan, kewajiban ini kemudian diturunkan kepada anak laki-lakinya yang sulung dan seterusnya. Anak perempuan menurut Kuncaraningrat (1986:360) tidak disebutkan dalam pemujaan kepada leluhur karena sesudah menikah yang diurus adalah arwah leluhur fihak suaminya.

\section{Kebudayaan China di Kota Singkawang}

Adat istiadat dan budaya China di Indonesia masih melekat kuat pada etnik China terutama pada generasi tua. Kondisi yang demikian lebih nampak pada masyarakat di daerah-daerah yang populasi etnik Chinanya cukup besar. Terlihat jelas bahwa antara agama dan budaya pada masyarakat China sering dicampuradukkan. Hal ini bisa dipahami karena dalam agama Khonghucu penghormatan kepada orang tua dimulai sejak mereka masih hidup hingga mereka meninggal dunia, dalam bentuk pemujaan leluhur. Menurut kepercayaan etnik China dalam hidup ini orang harus kerja keras agar memperoleh kekayaan sebanyakbanyaknya. Dengan kekayaan itu mereka dapat menghormati arwah leluhurnya secara layak. Budaya dan adat istiadat pada masyarakat etnik China yang lain misalnya dalam upacara perkawinan, kematian, masih dilestarikan sehingga dapat disaksikan sampai sekarang.

\section{Tekanan Hidup}

Konflik antaretnik yang sering terjadi di Indonesia, di antaranya yang disebabkan oleh kecemburuan sosial merupakan tekanan hidup bagi etnik China. Tekanan hidup tersebut secara lebih kuat telah mendorong semangat berwirausaha etnik China, karena mereka berpendapat bahwa bilamana mereka memiliki kemampuan materi dan berhasil dalam kehidupannya, mereka akan bisa memperoleh perhatian maupun perlindungan dari pihak yang memiliki kekuasaan, dalam hal ini pemerintah atau militer. Mereka semakin bersemangat untuk berwirausaha terutama bagi yang masih merasa miskin agar apabila menjadi kaya akan mudah memperoleh layanan pengamanan sehingga kekhawatiran tersebut berkurang.

Merujuk berbagai pendapat tentang tekanan hidup yang dialami oleh etnik China dan pengaruhnya terhadap kewirausahaan, dapat disarikan bahwa rasa aman merupakan kebutuhan dasar yang penting bagi mereka. Ancaman terhadap rasa aman mendorong mereka untuk lebih gigih berusaha agar dapat tampil terhormat dan dengan begitu akan memperoleh layanan perlindungan dan keamanan yang mereka butuhkan demi keamanan kehidupannya.

\section{Kehidupan Keluarga dan Kewirausahaan}

Lingkungan keluarga merupakan lingkungan yang pertama dan utama, terutama bagi anak usia balita, karena anak lahir pertama dalam lingkungan keluarga, mengalami proses sosialisasi yang pertama di lingkungan keluarga, sebagian besar waktunya ada dalam keluarga dan ini semua akan menentukan keberadaan anak lebih lanjut.

Keluarga adalah wahana strategis dalam pembentukan kepribadian anak. Menurut pendapat Zakiyah Daradjad (1991) pembentukan kepribadian itu dimulai dari dalam kandungan. Semua pengalaman yang dilalui pancaindera anak akan terserap dan masuk sebagai unsur kepribadian yang sedang dalam proses perkembangannya. Kepribadian ini termasuk di dalamnya kewirausahaan.

\section{Kerangka berpikir}

Pembinaan sikap kewirausahaan terhadap siswa SMK dilaksanakan sesuai dengan kurikulum yang berlaku. Sejak dari Kelas I sampai dengan Kelas III, siswa memperoleh pengetahuan, keterampilan dan pembentukan sikap untuk dapat mengembangkan kinerja kewirausahaan. Pelaksanaan pendidikan dan pelatihan yang diperoleh di SMK dipengaruhi oleh beberapa faktor baik yang berasal dari luar maupun dari dalam diri siswa serta baik yang bersifat internal dan faktor eksternal. 
Faktor yang bersifat internal tersebut yakni agama atau keyakinan yang bersifat spesifik pada etnik China Hakka di Singkawang. Antara kehidupan agama dengan budaya berhubungan sangat erat dan keduanya mempengaruhi keberhasilan berwirausaha. Apabila terdapat sinergi antara kehidupan dalam keluarga dengan Kurikulum Pendidikan yang berlaku di SMK dengan didukung oleh nilai-nilai budaya dan Agama etnik China maka akan terbentuk kinerja wirausahawan yang berhasil.

Proses pembentukan kewirausahaan dan faktor-faktor yang berpengaruh terhadap kewirausahaan etnik China Iulusan SMK di kota Singkawang dipengaruhi oleh faktor keluarga, agama, kepercayaan dan adat istiadat, serta faktor eksternal yang lain.

Faktor-faktor yang mempengaruhi kinerja pada etnik China lulusan SMK di kota Singkawang sehingga berhasil dalam usahanya sebagai wirausahawan dapat dilihat pada Gambar 1.

\section{Metodologi dan Teknik Penelitian Tempat dan Waktu Evaluasi}

Penelitian evaluasi ini berbasis pada latar budaya etnik China di kota Singkawang yang dipengaruhi kepercayaan, agama dan adat istiadat yang dibawa dari negeri leluhurnya, dan secara turun temurun dipelihara dan dilestarikan oleh warga etnik China. Latar tempat ini ditengarai berpengaruh terhadap kewirausahaan etnik China lulusan SMK di kota Singkawang. Penelitian evaluasi ini akan dilaksanakan secara langsung dengan berada di lapangan untuk melaksanakan pengumpulan data yang dimulai bulan Mei 2004 sampai dengan bulan September 2005. Penelitian ini dapat diperpanjang lagi sesuai dengan perkembangan hasil penelitian apabila hasilnya dianggap belum memadai.

\section{Metode Evaluasi}

Penelitian ini bermaksud mengevaluasi kinerja wirausahawan alumni SMK yang berlatar belakang etnik China di kota Singkawang. Untuk memperoleh informasi tentang karakteristik dan faktorfaktor yang mempengaruhi kewirausahaan menggunakan metode evaluasi kualitatif dengan mengeksplorasi pendapat, ide atau pandangan tentang kewirausahaan sebagai hasil pendidikan kejuruan dari para alumni SMK tersebut secara mendalam dan holistik.

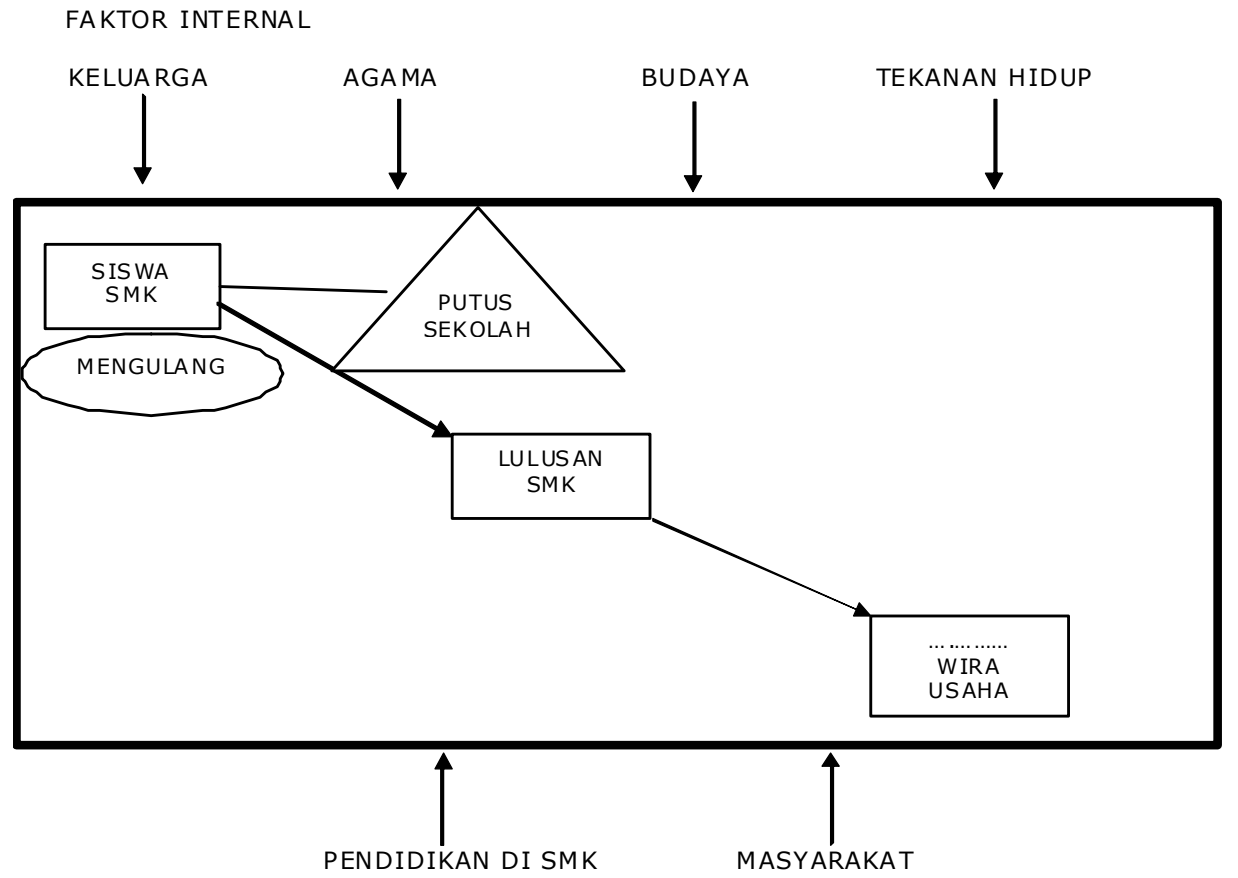

FAKTOR EKSTERNAL

Gambar 1. Proses dan Faktor yang Mempengaruhi Pembentukan Kewirausahaan Etnik China Lulusan SMK. 
Penelitian yang sesuai dengan latar ini adalah Penelitan Evaluasi dengan menggunakan pendekatan kualitatif Fenomenologic naturalistic. Penelitian fenomenologis ini mempunyai makna memahami suatu peristiwa, dalam hubungannya dengan orang dalam situasi tertentu.

Naturalistik diartikan sebagai pendekatan yang berlatar alamiah yang dapat digunakan sebagai sumber data utama. Dalam penelitian yang menggunakan pendekatan fenomenologis naturalistik ini peneliti berusaha untuk meneliti fenomena yang terjadi secara alamiah, bukan dalam kondisi laboratorium.

\section{Teknik Pengambilan Subjek Penelitian}

Dalam penelitian evaluasi ini orang yang dijadikan subjek penelitian diambil dengan cara purposive. Subjek penelitian evaluasi ini disebut dengan istilah "informan" dan bukan responden atau istilah yang lain, dengan pertimbangan bahwa penelitian ini banyak diwarnai data etnografis. Dalam pengumpulan data dibutuhkan berbagai informasi yang bersumber dari para informan yakni etnik China dari suku Hakka atau Khek yang unik dan berbeda dengan etnik China di daerah lain.

Penggunaan istilah Informan menurut Spradley (1997:35) mempunyai pengertian orang yang diminta untuk berbicara dalam bahasa atau dialeknya sendiri. Informan memberi contoh dan model untuk ditiru dengan menggunakan bahasa dengan cara yang dilakukan oleh informan. Informan merupakan sumber informasi dan menjadi guru bagi etnografer atau peneliti dalam studi ini.

Pemilihan subjek dalam penelitian ini didasarkan pada pertimbangan yang tidak kaku tetapi secara fleksibel sesuai dengan fenomena yang muncul di lapangan. Persyaratan secara individual untuk informan adalah lulusan SMK Singkawang dari etnik China berdasar usul pertimbangan dari para Kepala Sekolah/mantan Kepala Sekolah, para guru/mantan guru atau personil sekolah yang lain. Informan yang dalam pembahasan selanjutnya diistilahkan dengan informan kunci dinilai telah berwirausaha dan membuka usaha. Selain informan dari lulusan SMK juga dipilih satu orang informan lain yang bukan lulusan SMK sebagai "informan pembanding".

\section{Teknik Pengumpulan Data}

Data yang diperoleh dalam penelitian kualitatif berupa hasil observasi atau pengamatan langsung, hasil wawancara secara mendalam yang lebih mengutamakan pandangan dan pendirian informan sebagai subjek penelitian sehingga tergambar karakternya sebagai wirausahawan serta data yang diperoleh melalui sumber informasi yang lain. Informasi yang dikumpulkan tidak saja berupa informasi verbal dari informan tetapi juga tindakan dan aktivitasnya sebagai seorang wirausahawan.

\section{Prosedur Pengumpulan dan Perekaman Data}

Penelitian ini dimulai dengan tahap pengenalan setting melalui survai pendahuluan. Tujuannya adalah untuk mendeteksi situasi lapangan dan karakteristik subjek yang akan menjadi objek penelitian. Pengenalan setting telah dilakukan dari tanggal 10 Februari sampai dengan tanggal 14 Februari 2004 dan tanggal 17 sampai dengan 24 Februari 2004, dalam bentuk survai awal. Kegiatan yang dilakukan oleh peneliti bahkan perlu dilengkapi dengan pengetahuan teoretik tentang setting. Hal ini sesuai dengan pendapat dari Djaali (2005:6) yang menyatakan bahwa pengetahuan peneliti mengenai situasi lapangan dan karakteristik subjek (masyarakat atau kebudayaan tertentu) yang akan diteliti harus dilengkapi dengan pengetahuan teoritik yang diperoleh melalui telaahan kepustakaan sebelum peneliti melakukan pengumpulan data di lapangan.

\section{Teknik Analisis Data}

Analisis data dalam penelitian kualitatif menggunakan analisis secara induktif. Hasil analisis data bukan untuk menguji hipotesis seperti halnya pada penelitian kuantitatif. Data yang telah dikumpulkan kemudian dikelompokkan ke dalam tema, pola, dan kategori, dan untuk selanjutnya ditarik kesimpulan sementara dengan cermat dan hati-hati.

Analisis data dalam penelitian ini mengikuti prosedur Miles dan Hubermans (1992: 89) meliputi berbagai kegiatan, yakni reduksi data, penyajian dan verifikasi data serta penarikan simpulan. Proses tersebut terjadi sebelum pengumpulan data, pada masa perancangan studi, pada masa pengumpulan data, ketika analisis awal dilak- 
sanakan dan setelah penarikan dan pengumpulan data sebagai hasil-hasil akhir hampir dicapai dan diselesaikan

Bagan alur dari analisis data dari Miles dan Hubermans tersebut dapat digambarkan secara grafis pada Gambar 2.

\section{Pengecekan keabsahan data}

Melalui pengecekan keabsahan data dapat diperoleh beberapa manfaat karena masingmasing memiliki fungsi yang berbeda-beda. Kepercayaan (credibility) untuk aspek kebenaran data, keteralihan (transferability) untuk sejauh mana hasil penelitian dapat diaplikasikan atau digunakan pada situasi lain. Ketergantungan (dependebility) untuk aspek konsistensinya sedangkan kepastian (confirmability) untuk aspek netralisasi. Penelitian yang membahas perilaku tentang etnik China tidak jarang diwarnai dengan prejudise, stereotype, dan kungkungan konsep, proposisi dan teori-teori tertentu. Melalui kegiatan pengecekan keabsahan data ini kemungkinan terjadinya bias dalam penelitian dapat dihindari.

\section{Perencanaan Kegiatan Penelitian}

Perencanaan Kegiatan Evaluasi dalam penelitian ini dapat digambarkan dalam Tabel 3.

\section{Pembahasan}

Temuan hasil penelitian dalam bentuk dialogis dari hasil wawancara mendalam setelah diolah kemudian dituangkan dalam bentuk narasi sehingga berbentuk analisis kasus dan lebih mudah dipahami. Bentuk narasi kemudian dilanjutkan pengolahannya sehingga dapat disajikan dalam bentuk matriks.

\section{Kewirausahaan etnik China Iulusan SMK di Kota Singkawang}

Studi ini berhasil mengidentifikasi karakteristik wirausahawan lulusan SMK di kota Singkawang. Para wirausahawaan etnik China Iulusan SMK Singkawang diharapkan memiliki karakteristik yang bersifat umum yaitu percaya diri, berorientasi pada kerja dan hasil, berani mengambil risiko, memiliki jiwa kepemimpinan, keorisinalan dan berorientasi ke masa depan.

Karakteristik umum para informan yang terekam dari hasil bahasan dalam penelitian ini adalah tumbuhnya Sikap percaya diri.

\section{Percaya diri}

Sikap percaya diri tumbuh dengan baik pada diri para wirausahawan Iulusan SMK Singkawang. Penyebab tumbuhnya sikap percaya diri ini ada tiga hal yaitu: 1) pernah memperoleh pengalaman dan sempat menyelesaikan suatu pekerjaan yang dipercayakan oleh orang lain maupun proyek yang diciptakan sendiri; 2) pekerjaan yang ditangani itu mendatangkan keuntungan maka semakin berani berusaha; 3) pada umumnya para informan Iulusan SMK dalam penelitian ini pernah mengalami keberhasilan-keberhasilan sehingga rasa percaya dirinya makin tinggi.

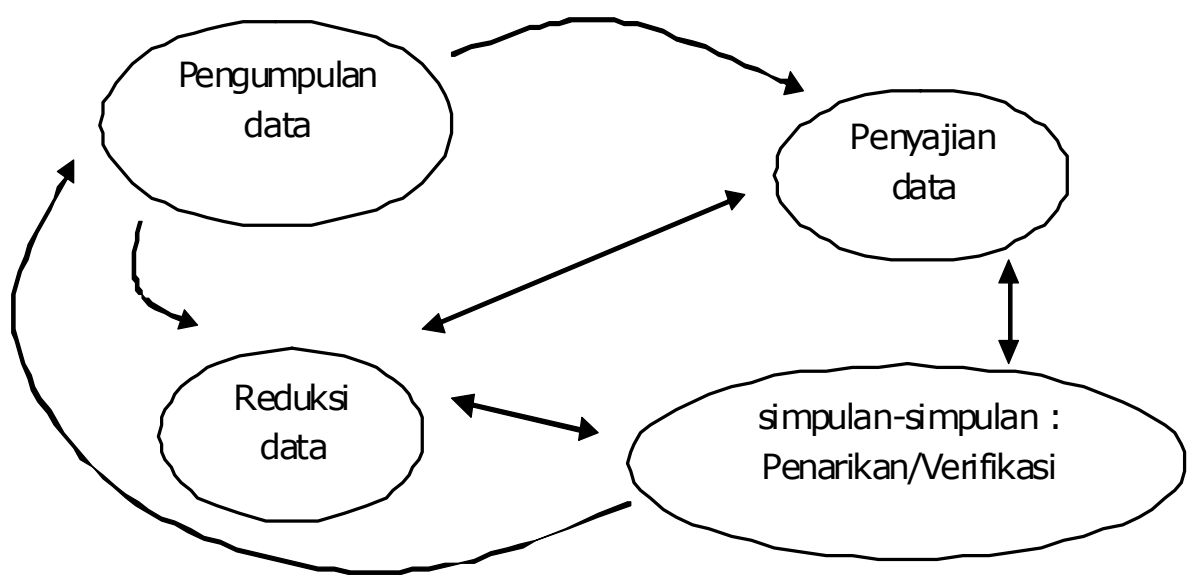

Gambar 2. Komponen-komponen Analisis Data Model Interaktif

(Sumber: Miles, 1992, Analisis Data Kualitatif) 
Tabel 3. Rencana Kegiatan Penelitian Evaluasi Kinerja Kewirausahaan Etnik China Iulusan SMK di kota Singkawang

\begin{tabular}{|c|c|c|}
\hline Kegiatan & Alat Pengumpul Data & Data yang dihimpun \\
\hline 1 Pra penelitian & $\begin{array}{l}\text { Dokumen, pustaka. } \\
\text { Wawancara dan } \\
\text { observasi. }\end{array}$ & $\begin{array}{l}\text { - Sejarah kedatangan imigran China } \\
\text { Hakka di Singkawang } \\
\text { - Adat istiadat etnik China } \\
\text { - Agama, kosmologi China. } \\
\text { - Data penduduk etnik China mata } \\
\text { pencaharian } \\
\text { - Budaya dan kehidupan sosial China di } \\
\text { Singkawang } \\
\text { - Kepercayaan yang lain }\end{array}$ \\
\hline $\begin{array}{l}\text { 2. Kunjungan } \\
\text { sekolah }\end{array}$ & $\begin{array}{l}\text { Pedoman Observasi } \\
\text { Arsip. } \\
\text { Wawancara. }\end{array}$ & $\begin{array}{l}\text { - Fasilitas } \\
\text { - Guru } \\
\text { - Kurikulum } \\
\text { - Siswa. }\end{array}$ \\
\hline $\begin{array}{l}\text { 3.Pelaksanaan } \\
\text { Penelitian }\end{array}$ & $\begin{array}{l}\text { Observasi partisipatif } \\
\text { PedomanWawancara. }\end{array}$ & $\begin{array}{l}\text { - Program Pendidikan Kejuruan } \\
\text { - Praktek kewirausahaan di SMK } \\
\text { - Pendidikan Kejuruan di SMK } \\
\text { Singkawang. } \\
\text { - Pendidikan Kewirausahaan. } \\
\text { - Kondisi tempat usaha. } \\
\text { - Kemajuan Usaha } \\
\text { - Pola perdagangan } \\
\text { - Penilaian karakter kewirausahaan } \\
\text { - Faktor yang mempengaruhi } \\
\text { kewirausahaan. }\end{array}$ \\
\hline $\begin{array}{l}\text { 4. Penyajian dan } \\
\text { analisis data }\end{array}$ & Matriks Analisis. & Data dialogis, Matriks Analisis \\
\hline
\end{tabular}

\section{Sikap Optimisme}

Analisis terhadap rasa optimisme berhasil pula terungkap dalam studi ini. Para informan sebagai seorang wirausahawan Iulusan SMK pada umumnya memiliki rasa optimisme yang tinggi untuk berhasil dalam mengelola usaha. Masingmasing informan yang terpilih memiliki cara tersendiri dalam mengungkap optimisme keberhasilan bisnisnya

Dari hasil wawancara mendalam, studi ini berhasil mengungkap bahwa rasa optimisme para wirausahawan alumni SMK di kota Singkawang berkembang karena pengalaman mereka yang berhasil dalam menangani usaha dan berhasil memperoleh keuntungan. Optimisme yang tinggi membuat wirausahawan tidak takut menghadapi kegagalan karena kegagalan dapat dikalahkan oleh usaha keras dan rasa optimisme yang tinggi. Rasa optimisme bagi wirausahawan etnik China lulusan SMK di kota Singkawang ini tumbuh dengan subur karena dipupuk sejak kecil di lingkungan keluarga, dipelajari di sekolah, dilatih di masyarakat dan dituntut oleh persaingan dalam usaha di masyarakat.
Berdasarkan hasil analisis terhadap kinerja dari para informan dan dibandingkan dengan indikator dalam penelitian ini, dapat diperoleh temuan bahwa keberhasilan yang dicapai dalam berusaha memerlukan keberanian untuk masuk ke gelanggang dalam hal ini berwirausaha disertai keyakinan dan optimisme yang tinggi seseorang akan sukses dalam berusaha

\section{Orientasi Tugas dan Hasil}

Analisis dari hasil wawancara tentang karakteristik wirausahawan dari ikhtisar hasil wawancara mendalam dengan para informan dapat diperoleh berbagai informasi. Para informan sependapat bahwa orientasi tugas dan hasil usaha ini diwujudkan dalam bentuk karakteristik. Adapun karakter tersebut nampak pada kebutuhan akan prestasi, berorientasi laba, ketekunan dan ketabahan, tekad dan kerja keras, mempunyai dorongan kuat, enerjik, dan punya inisiatif.

Memang tidak mudah untuk menilai wirausahawan yang memiliki karakter berorientasi tugas dan hasil. Lebih-lebih apabila harus menerapkan berbagai kriteria dan sederet 
karakteristik terhadap watak pribadi yang bermacam ragam.

\section{Kebutuhan Akan Prestasi}

Kebutuhan akan prestasi ternyata merupakan kebutuhan bagi setiap orang. Dalam kehidupan pribadi tiap-tiap individu terdapat suatu kebutuhan akan prestasi yang menuntut untuk dipenuhi. Bagi seorang wirausahawan etnik China kebutuhan akan prestasi itu sebagai kebutuhan yang bersifat psikis. Orang akan berusaha memenuhi dan menyalurkan kebutuhan berprestasi dengan berbagai cara dan usaha.

Dari hasil analisis indikator tentang kebutuhan akan prestasi diperoleh temuan bahwa para informan adalah wirausahawan yang memiliki karakter kebutuhan berprestasi yang tinggi. Tingginya semangat untuk merealisir kebutuhan tersebut menjadikan para informan menjadi wirausahawan yang berhasil dalam menangani usahanya. Bahkan kebutuhan berprestasi ini mengarah pada target mengejar kekuasaan.

\section{Orientasi Laba}

Hasil wawancara mendalam terhadap para informan diperoleh informasi tentang karakteristik orientasi mereka pada keuntungan atau laba finansial berupa uang. Dari hasil wawancara mendalam terhadap informan diperoleh informasi bahwa orientasi laba finansial menurut Wirausahawan etnik China lulusan SMK Singkawang ini adalah sesuatu yang wajar dan bahkan sesuatu keharusan dalam bisnis. Manifestasinya dalam berwirausaha, karakter mementingkan laba atau keuntungan berupa uang ini berbeda-beda dalam menyikapinya antara informan satu dengan yang lain.

Dari studi ini diperoleh temuan bahwa karakter wirausahawan etnik China tamatan SMK Singkawang kaitannya dengan keuntungan materi ternyata bersifat manusiawi dan santun. Bisnis harus mementingkan keuntungan jangka panjang, dan tidak hanya mementingkan keuntungan yang bersifat temporer atau sesaat berupa keuntungan materi saja.

\section{Tekun dan Tabah}

Dalam bahasan ini pada umumnya etnik China tekun dan tabah dalam menangani bisnis.
Ketekunan dan ketabahan menurut informan bukan karena mereka etnik China akan tetapi lebih banyak dipengaruhi oleh pribadi masing-masing.

Terdapat perbedaan konsep tentang kejenuhan dan kebosanan dalam usaha pada para informan. Kebosanan adalah indikator awal keberhasilan usaha. Pandangan tentang heng (keberuntungan) dan hokki atau keberuntungan dalam bisnis ditandai dengan kebosanan yang harus dihadapi dengan ketekunan dan ketabahan. Kepercayaan dan keyakinan dalam bisnis etnik China tentang kebosanan yang mendatangkan peningkatan produktivitas dalam bisnis. Kejenuhan dan kebosanan dapat dijadikan sebagai indikator datangnya keberhasilan dalam usaha dan dapat meningkatkan produktivitas.

Dari berbagai tanggapan tentang ketekunan dan ketabahan dan hasil pengamatan di tempat usahanya diperoleh temuan bahwa para informan adalah wirausahawan yang memiliki karakteristik tekun dan tabah. Dari indikator yang ada, ketekunan dan ketabahan bukan disebabkan oleh latar belakang etniknya, namun lebih di tentukan oleh pribadinya dan cara menanggapi kejenuhan dan kebosanan dalam mengelola usaha.

\section{Tekad dan Kerja Keras}

Analisis data dalam studi ini menunjukkan bahwa etnik China lulusan SMK di kota Singkawang memiliki tekad dan kerja keras yang tinggi. Salah seorang Informan menyatakan bahwa tekad dan kerja keras etnik China di kota Singkawang lebih banyak disebabkan oleh tekanan ekonomi. Karena sosial ekonomi yang rendah maka mereka mempunyai tekad dan kerja keras.

Dari pendapat-pendapat informan dapat disimpulkan bahwa kerja keras tidak ditentukan oleh latar belakang etnik tetapi lebih ditentukan oleh latar belakang sosial ekonomi yang masih kurang. Namun, bila dibandingkan dengan etnik lain etnik China Hakka memang memiliki karakter pekerja keras dan memiliki tekad yang keras juga.

\section{Energik dan Penuh Inisiatif}

Analisis dalam studi ini menunjukkan bahwa wirausahawan harus enerjik dan penuh inisiatif. Pada waktu masih muda seorang wirausahawan cenderung untuk lebih enerjik bila dibanding dengan wirausahawan yang telah tua. Dari 
fenomena dan analisis matriks indikator menunjukkan bahwa kehidupan etnik China dalam menangani usaha pada waktu muda mereka enerjik dan kreatif membangun bisnis, di hari tua pun ada yang tetap menekuni usaha.

Namun ada juga yang menikmati hidup masa tua dengan bersantai. Nama mereka masuk dalam daftar deretan antrian nama arwah leluhur yang harus dipuja oleh anak cucunya. Falsafah yang cocok bagi kehidupan etnik China adalah " Masa muda giat untuk membangun usaha, setelah tua menikmati hidup berbahagia, sesudah mati masuk dalam deretan arwah leluhur" yang dipuja, dihormati dan dimintai berkat oleh anak cucunya.

\section{Pengambil risiko}

Dari bahasan hasil analisis matriks indikator penelitian ini menunjukkan bahwa para informan baik informan kunci maupun informan pembanding adalah pengambil risiko yang berani. Analisis ini didasari pada kenyataan pribadinya dan pernyataan-pernyataan yang dibuatnya. Pada umumnya para informan menyatakan bahwa apabila dihadapkan pada situasi yang berisiko dalam bisnis, mereka akan menghadapinya dan tidak akan menghindarinya

Dari pendapat para informan kunci dan informan pembanding dapat dianalisis bahwa dalam menjalani bisnis selalu dihadapkan pada berbagai risiko. Para informan kunci berpendapat sama bahwa risiko adalah keseimbangan antara modal yang dikeluarkan dengan hasil yang akan dicapai. Kondisi dan situasi perlu untuk diperhitungkan dengan baik oleh wirausahawan dalam menentukan suatu sikap atau pengambilan keputusan. Wirausahawan harus memahami dengan benar situasi dan kondisi usahanya pada saat akan menentukan sikap. Para wirausahawan etnik China lulusan SMK Singkawang meyakini benar situasi dan kondisi usahanya masing masing sehingga berani menentukan sikap dengan tepat dan berani dalam menghadapi situasi yang berisiko.

\section{Suka pada Tantangan}

Berdasarkan hasil analisis terhadap pandangan para wirausahawan tentang tantangan yang dihadapi dalam bisnis, ternyata informan pada umumnya menyukai sesuatu yang menantang dalam berbisnis. Jenis tantangan masing-masing wirausahawan lulusan SMK berbeda sesuai dengan bisnis yang ditangani

Secara umum sikap terhadap tantangan dalam bisnis ada tiga hal, yaitu: 1) pada umumnya pengusaha menyukai bisnis yang penuh dengan tantangan karena menjadikan bisnisnya menjadi lebih menyenangkan dibanding kondisi yang biasabiasa saja; 2) tantangan dalam bisnis bersifat spesifik sesuai dengan bisnisnya masing-masing namun dengan dihadapkan pada tantangan menjadikan bisnis lebih dinamis; 3) tantangan dalam bisnis kadang diciptakan sendiri oleh pengusaha dengan melakukan ekspansi atau mencoba cara baru yang belum pernah dilakukan oleh orang lain.

Dari pengalaman sejarah menunjukkan bahwa iklim usaha di kota Singkawang adalah bisnis yang penuh dengan tantangan terutama faktor keamanan. Antara aman dan tidak aman bagi etnik China adalah bersifat fluktuatif. Pengalaman sejarah ini telah dipahami dan dijiwai benar oleh para pengusaha etnik China di Singkawang sebagai suatu tantangan. Mereka menghadapinya sebagai suatu tantangan dari nenek moyang hingga mereka sebagai anak cucunya sekarang. Dari kondisi yang demikian tantangan adalah sesuatu yang biasa dan harus dihadapi dan ditaklukkan. Tantangan menjadikan pengusaha mempunyai sikap selalu waspada terhadap situasi lingkungan. Dengan menghadapi berbagai tantangan makin mendekatkan diri para usahawan etnik China pada" bhakti" kepada arwah nenek moyang serta berharap akan datangnya keberuntungan dalam usahanya.

\section{Kepemimpinan}

Bisnis selalu membutuhkan kepemimpinan yang kuat dari seorang wirausahawan. Untuk dapat menjalankan bisnisnya dengan baik seorang wirausahawan paling tidak memiliki karakter atau sifat-sifat sebagai pemimpin, dapat bergaul dengan orang lain, dapat menanggapi saransaran dan kritik dengan tepat dan benar.

Dari berbagai pendapat tentang kepemimpinan dalam bisnis etnik China di Singkawang dapat diambil ciri umum bahwa bisnis etnik China lulusan SMK Singkawang adalah bisnis keluarga. Dalam bisnis yang berbasis keluarga peran 
pimpinan adalah bersifat paternalistik, artinya pimpinan yang ke-bapa-an, melindungi, mengayomi dan memotivasi bawahan untuk bekerja dengan baik di samping menuntut kepatuhan, loyalitas yang tinggi terhadap pemimpin dari para stafnya.

\section{Dapat Bergaul dengan Orang Lain}

Hasil bahasan menunjukkan bahwa karakter atau watak kepemimpinan tercermin pada masingmasing individu dalam membina hubungan dengan orang lain. Pada umumnya informan adalah orang yang terkemuka dan terpandang di Singkawang baik di antara sesama etnik China maupun di lingkungan masyarakat. Kedudukan informan pada umumnya sebagai tokoh masyarakat di bidang keagamaan, di bidang politik atau sebagai pengusaha memiliki peluang bagi mereka untuk memperluas pergaulan dengan orang lain.

Dari berbagai pandangan tersebut dapat dirumuskan temuan dalam penelitian ini bahwa para wirausahawan etnik China memiliki komitmen membina hubungan baik dengan semua kalangan tanpa pilih kasih demi memperoleh keuntungan jangka panjang dalam bisnis.

\section{Menanggapi Saran dan Kritik}

Karakteristik kemampuan di dalam menanggapi saran dan kritik ini dicerminkan oleh para pengusaha etnik China lulusan SMK Singkawang dalam pendekatannya dengan staf dan anak buahnya.

Bisnis keluarga lebih berorientasi pada orang dan hubungan manusiawi sehingga lebih banyak memotivasi staf untuk bekerja lebih baik. Dari hasil analisis indikator karakteristik kepemimpin dalam berwirausaha dapat diambil pernyataan sebagai hasil temuan penelitian ini bahwa: Dalam pembinaan kewirausahaan etnik China Iulusan SMK Singkawang yang berorientasi pada bisnis yang berbasis keluarga, memungkinkan hubungan yang lebih akrab dan luwes. Hubungan antara pimpinan dan staf dalam bisnis yang berorientasi bisnis keluarga lebih bersifat interpersonal relation sehingga staf dapat saja memberikan saran dan kritik secara langsung demi kemajuan usaha.

\section{Keorisinalan}

Wirausahawan yang maju membutuhkan ide-ide yang orisinil dalam mengelola usaha. Dengan ide yang orisinil usaha akan lebih menarik, maju dan disenangi orang lain. Watak dan karakter wirausahawan yang berciri orisinal adalah inovatif dan kreatif, fleksibel, punya banyak sumber, serba bisa dan mengetahui banyak.

\section{Inovatif dan Kreatif}

Karakteristik inovatif dan kreatif para informan dalam studi ini tercermin dari pandangan dan persepsi tentang inovasi. Adanya ide-ide baru dan kreativitas dalam mengembangkan usaha. Pada umumnya informan kunci para wirausahawan etnik China lulusan SMK Singkawang menyukai ideide baru namun menurut mereka sebenarnya tidak ada ide-ide baru dalam bisnis sekarang ini. Sesuatu yang baru di Indonesia sebenarnya sudah tidak baru lagi di negara lain. Sesuatu yang dianggap up to date di Indonesia sudah out of date di negara lain.

Pernyataan yang dapat diungkap dari matriks analisis indikator dalam studi ini adalah dalam melakukan bisnisnya para wirausahawan etnik China lulusan SMK di kota Singkawang yang dipilih sebagai informan dalam penelitian ini berusaha secara kreatif memperkenalkan ide-ide dan penampilan baru sehingga dengan kreativitas itu memperoleh berbagai kemajuan dalam usahanya.

\section{Fleksibel}

Wirausahawan yang terpilih pada umumnya memiliki fleksibilitas yang tinggi, watak atau karakter fleksibel ini merupakan watak yang tidak kaku dan mudah ditolerir. Artinya, orang yang memiliki karakteristik fleksibel akan mudah menyesuaikan diri dengan kebutuhan, situasi kondisi maupun kecenderungan yang ada. Sebagai seorang wirausahawan harus fleksibel dalam mengelola waktu, mengelola dana atau anggaran, mengelola sumber daya yang lain.

Dari watak dan karakteristik wirausahawan yang dipilih dalam hubungan dengan fleksibilitas, studi ini memperoleh beberapa pernyataan yang sangat berharga dalam kewirausahaan etnik China lulusan SMK Singkawang. Pertama, fleksibilitas menurut wirausahawan etnik China tamatan SMK Singkawang diartikan sebagai 
upaya untuk meningkatkan produktivitas. Bisnis etnik China lulusan SMK Singkawang adalah bisnis yang unik dan spesifik dalam mendefinisikan fleksibilitas. Sesuatu yang mempunyai konotasi santai namun mendatangkan rejeki. Ada rejeki yang inconventional sebagai rejeki malam hari di samping rejeki siang yang biasa diperolehnya secara conventional. Kedua, dalam menangani bisnis ada suatu prinsip dalam hubungan dengan fleksibilitas. Bisnis dapat dimainkan tetapi jangan bermain-main dalam berbisnis. Artinya dalam berwirausaha kita dapat fleksibel, berimprovisasi, dan bereksperimen. Jangan kaku akan tetapi harus tetap serius dan berdisiplin tinggi. Ketiga, apapun kiat yang dia lakukan adalah upaya bagaimana memperoleh keuntungan-keuntungan dalam usahanya.

\section{Memiliki Banyak Sumber}

Dalam studi ini terungkap bahwa pada umumnya wirausahawan etnik China lulusan SMK Singkawang yang terpilih telah membentuk jejaring (net-working) sesama wirausahawan yang sejenis. Di samping itu juga membentuk jaringan bisnis sesama keluarga, sesama marga untuk memperlancar dan memperkuat bisnisnya.

Para wirausahawan etnik China lulusan SMK Singkawang memanfaatkan sebaik-baiknya momen-momen tertentu untuk memperluas hubungan dan dengan makin luasnya hubungan makin banyak sumber untuk pengembangan bisnisnya.

\section{Serba Bisa dan Mengetahui Banyak}

Untuk dapat mengelola usaha dengan baik seorang wirausahawan harus serba bisa dan mengetahui banyak tentang seluk beluk usahanya.

Ungkapan para informan menunjukkan bahwa wirausahawan perlu meningkatkan diri, memperluas wawasan usahanya. Wirausahawan yang berhasil adalah wirausahawan yang tahu banyak tentang bisnisnya dan serba bisa meskipun tidak sampai ke detailnya. Wirausahaan yang berhasil lebih banyak mendelegasikan wewenangnya kepada anak buahnya.

\section{Orientasi Ke Masa Depan/Perspektif}

Hasil bahasan dalam studi ini terungkap bahwa pada umumnya wirausahawaan yang dipilih sebagai informan kunci adalah wirausahawan yang selalu berfikir fokus. Mereka tidak pernah berfikir tentang pengganti usaha karena yakin usaha yang ditanganinya feasible untuk waktu yang lama. Pada umumnya wirausahawan berpendapat bahwa bisnis perlu perencanaan yang matang dan rapi untuk mendukung perspektif pengembangannya di masa mendatang.

Dari berbagai pendapat tersebut diperoleh temuan bahwa para wirausahawan etnik China lulusan SMK yang dipilih memiliki komitmen yang tinggi terhadap usahanya. Mereka senantiasa berfikir fokus dalam arti tidak berniat mengganti usahanya, mereka menganggap bisnisnya feasible untuk masa yang akan datang bahkan ada yang ingin mengajak investor lain untuk menanamkan modalnya dan mengembangkan usahanya.

Dari analisis matriks indikator, dapat dinyatakan bahwa para usahawan yang terpilih sebagai informan dalam penelitian ini baik informan kunci maupun informan pembanding adalah wirausahawan yang memiliki pandangan ke depan yang perspektif dan penuh optimisme. Para wirausahawan etnik China lulusan SMK Singkawang adalah wirausahawan yang punya perspeksi masa depan usaha.

\section{Faktor-faktor yang Mempengaruhi Kewirausahaan Etnik China Lulusan SMK di Kota Singkawang}

Dari hasil analisis data tentang faktor yang berpengaruh terhadap kewirausahaan etnik China diperoleh temuan bahwa faktor agama, kepercayaan, adat istiadat dan budaya masih sangat kental pengaruhnya terhadap kinerja kewirausahaan etnik China. Faktor-faktor tersebut senantiasa dipelihara dan dipertahankan dalam kehidupan sehari-hari secara turun temurun dari nenek moyangnya hingga sekarang. Pengabdian kepada arwah para leluhur sebagai kepercayaan yang berdasarkan pada ajaran agama Khonghucu sangat mewarnai kehidupan sebagai bisnis yang berbasis keluarga. Kehidupan bermasyarakat dan kehidupan sosial di kota Singkawang ikut mewarnai kinerja dan lebih 
diperdalam lagi di SMK dalam bentuk pembelajaran sehingga diperoleh pengetahuan, keterampilan dan pembentukan sikap dalam berwirausaha.

Dari fase perkembangan kewirausahaan etnik China lulusan SMK Singkawang tersebut dapat diambil pernyataan sebagai hasil pembahasan studi kasus ini bahwa kewirausahaan bukan sekedar faktor bakat, bawaan atau faktor yang dapat diajarkan. Menurut para informan kewirausahaan adalah merupakan proses yang dimulai dari faktor pembiasaan atau pembentukan kebiasaan yang dimulai sejak kanak-kanak dalam kehidupan keluarga secara berangsur-angsur hingga mencapai kematangannya dimasyarakat.

Dari berbagai pendapat pernyataan para informan dan didukung oleh penelitian yang dilakukan ternyata keberhasilan berwirausaha banyak di pengaruhi oleh berbagai faktor. Kontribusi pendidikan dalam pembentukan kewirausahaan dinilai para informan dalam penelitian ini hanya sebatas memperoleh pengetahuan, keterampilan dan sikap untuk berani berwirausaha. Modal pendidikan di SMK baru sebatas teori dan pengetahuan tentang bagaimana cara berwirausaha dan membentuk sikap atau jiwa berwirausaha.

Dari berbagai gambaran yang menonjol latar belakang kehidupan keluarga dan pengaruhnya terhadap wirausaha etnik China dapat diambil beberapa pernyataan temuan dalam studi ini bahwa Tiap keluarga etnik China lulusan SMK di Kota Singkawang yang dipilih sebagai informan dalam penelitian ini memiliki bisnis atau usaha yang dikelola secara bersamaan oleh seluruh anggota keluarga termasuk anak yang masih kanak-kanak.

Semua anggota keluarga sejak usia dini ikut bertanggung jawab terhadap bisnis yang ditangani dan merupakan budaya yang turun temurun dan tetap dipertahankan hingga dewasa. Keterlibatan anak dalam bisnis keluarga sejak usia dini itu berhasil membentuk kebiasaan (habit forming) bagi anggota keluarga sejak dari usia kanak-kanak dan sangat besar nilainya bagi kehidupan usaha yang akan datang. Bahkan dalam pengamatan penelitian ternyata bahwa, hampir semua keluarga etnik China dinyatakan memiliki usaha.
Faktor-faktor tersebut bersinergi dan saling mendukung dalam membentuk kinerja kewirausahaan etnik China lulusan SMK di kota Singkawang.

\section{Simpulan dan Saran Simpulan}

Mengacu pada temuan penelitian dan hasil evaluasi kinerja wirausahawan etnik China lulusan SMK di kota Singkawang dapat ditarik simpulan sebagai berikut

Pertama, lulusan SMK Singkawang dari hasil evaluasi dan hasil bahasan memiliki karakteristik kewirausahaan yang mendukung. Para wirausahawan etnik China lulusan SMK di kota Singkawang dari hasil evaluasi dalam studi ini memiliki Karakteristik percaya diri yang tinggi, berorientasi tugas dan hasil, memiliki kemampuan mengambil risiko terhadap berbagai tantangan yang dihadapi.

Kepemimpinan para wirausahawan dalam studi ini, mulai terbentuk sejak mengikuti pendidikan di SD, SMP dan SMK Singkawang, baik sebagai Ketua Kelas, Ketua OSIS bahkan sebagai ketua IKOSIS. Kepemimpinan ini berlanjut setelah hidup di masyarakat sebagai ketua Organisasi Keagamaan, organisasi Politik/Partai, organisasi yang mengurus kepentingan sesama etnik China suku Hakka di Singkawang bahkan di Kalimantan Barat.

Ciri orisinalitas tercermin dari usahausahanya yang kreatif dan inovatif meski diakui oleh para informan apa yang dikembangkan di Singkawang telah banyak dilakukan di tempat lain di Indonesia terutama di luar negeri.

Meskipun diakuinya kreativitas dan inventifitasnya sudah tidak murni lagi namun usaha ke arah itu telah berhasil mengantarkan usahanya ke jenjang bisnis yang diperhitungkan di Singkawang. Usaha yang dikelola oleh wirausahawan dalam kasus ini diminati oleh penduduk kota Singkawang dan sekitarnya sehingga menuntut fleksibilitas dalam pengelolaannya.

Untuk menjamin kelangsungan usahanya para wirausahawan dalam studi ini telah membentuk dan membina jejaring (net-working) masing-masing.

Kedua, dari berbagai temuan-temuan penelitian terbukti bahwa pembentukan 
kewirausahaan etnik China lulusan SMK dipengaruhi berbagai faktor. Faktor-faktor yang mempengaruhi kewirausahaan adalah faktor agama, budaya, tekanan hidup, keluarga, faktor pendidikan, dan lingkungan masyarakat. Faktor yang mempengaruhi ada yang bersifat internal maupun ada juga yang bersifat eksternal yang ikut menentukan keberhasilan wirausahawan etnik China lulusan SMK Singkawang.

Faktor agama bagi etnik China adalah faktor yang berhubungan sangat erat dengan budaya. Ada kepercayaan menghormati orang tua dan arwah para leluhur baik yang masih hidup atau yang telah meninggal dunia adalah kewajiban dari anak cucunya. Memberikan penghormatan yang sesuai dengan semestinya terhadap arwah para leluhur akan berdampak positif terhadap bisnis dan usaha. Sebaliknya, ada keyakinan bahwa penghormatan yang kurang semestinya lebih lebih menterlantarkan leluhur akan berdampak negatif terhadap usaha.

Faktor keluarga menunjukkan bahwa wirausahawan pada umumnya adalah anak lakilaki dengan kedudukan kelahiran pada tingkatan kakak atau abang. Anak laki-laki pada kedudukan abang dalam keluarga etnik China suku Hakka atau khek sangat berpengaruh dalam tugas penghormatan kepada leluhur dan kewajiban meneruskan marganya sehingga sangat dituntut dalam meneruskan bisnis keluarganya. Faktor agama dan budaya bagi etnik China suku Hakka lulusan SMK di kota Singkawang dalam penelitian ini selalu dikaitkan dengan kehidupan bisnis dan usaha.

Budaya etnik China di Singkawang sangat dipelihara dan dilaksanakan dengan baik agar selalu diberkati usahanya oleh arwah leluhur mereka. Anak laki-laki mempunyai tugas sebagai penerus ayah dalam memimpin pemujaan kepada arwah para leluhur dan meneruskan bisnis keluarga.

Budaya bisnis yang berbasis keluarga sangat mementingkan keterlibatan seluruh anggota keluarga. Apabila anggota keluarga tidak mencukupi untuk menangani usaha, baru mengambil tenaga dari luar keluarga yang masih ada hubungan darah atau sesama etnik China karena lebih bisa menjaga rahasia dan etos kerjanya tinggi.
Faktor tekanan hidup sangat berpengaruh terhadap keberhasilan etnik China dalam berwirausaha. Karena tekanan sosial ekonomi maka mereka berjuang dengan gigih dan bersemangat sehingga usahanya berhasil. Karena tidak ada kesempatan untuk memperoleh pekerjaan lain selain berwirausaha maka etnik China Singkawang berusaha untuk berhasil dalam usahanya. Karena peluang usaha merupakan satu-satunya peluang yang ada maka mereka berjuang untuk tidak mengalami kegagalan dalam berusaha.

Ketiga, Program Pendidikan Kejuruan yang diperoleh di SMK yang dapat diklasifikasikan faktor eksternal sangat berperan dalam memberi dasar pengetahuan, sikap dan keterampilan dalam berwirausaha. Keberhasilan berwirausaha di samping telah dibina sejak kecil di lingkungan keluarga lebih dilengkapi lagi di sekolah. Melalui Pendidikan di SMK. Calon wirausahawan memperoleh berbagai pengetahuan, keterampilan dan pembentukan sikap sejak kelas I hingga Kelas III dalam bentuk matapelajaran Kewirausahaan dan mata Pelajaran Pendidikan Kejuruan yang lain.

Keterampilan lain dikembangkan sendiri dalam bentuk pengalaman yang sebenarnya setelah membuka usaha di masyarakat. Pengetahuan kewirausahaan yang diperoleh di sekolah dahulu dinilai oleh para wirausahawan lulusan SMK Singkawang bukan sekedar untuk mengerti tentang berwirausaha melainkan juga sangat mendukung setelah berwirausaha.

Pengalaman belajar di SMK memberi arti tersendiri dalam kehidupan dan pengalaman usaha. Wirausahawan etnik China Iulusan SMK memiliki cara pandang terhadap para guru yang telah mendidiknya dan memiliki guru idola yang disegani dan dihormati. Guru dianggap sebagai tokoh yang berjasa sehingga menempatkan kedudukan para gurunya termasuk dalam deretan orang yang harus dihormati karena jasa-jasa yang pernah diberikan kepadanya.

Terbukti pula bahwa terdapat sinergi antara faktor-faktor yang mempengaruhi kewirausahaan dengan pendidikan di SMK yang diikuti oleh siswa etnik China Sinergi tersebut mejadikan kondisi yang saling mendukung antara faktor pendidikan dengan faktor yang berpengaruh terhadap 
kewirausahaan yakni faktor kepercayaan/agama, kebudayaan, adat istiadat dan tekanan hidup. Faktor-faktor yang berpengaruh tersebut ternyata lebih mendukung keberhasilan dalam berwirausaha.

Keempat, terdapat perbedaan karakteristik wirausahawan Iulusan SMK dengan wirausahawan bukan lulusan SMK. Dari hasil analisis matriks indikator ternyata karakteristik wirausahawan lulusan SMK lebih mendukung dibanding dengan yang bukan lulusan SMK. Perbedaan itu lebih disebabkan oleh perbedaan latar belakang penguasaan pengetahuan, keterampilan dan sikap yang dibawa yang mendasari kewirausahaan seseorang.

Lulusan SMK lebih banyak mem-peroleh pembinaan kewirausahaan sejak dari awal pendidikan baik secara teori maupun secara praktik, dari kelas I hingga kelas III. dibanding dengan yang bukan lulusan SMK. Lulusan SMK ternyata lebih mendukung dalam berwirausaha dibanding dengan yang bukan dari SMK. Dalam berwirausaha lulusan SMK lebih mengutamakan keuntungan jangka panjang dan bukan keuntungan material semata.

Kelima, terbukti bahwa Kewirausahaan etnik China lulusan SMK di Kota Singkawang dalam penelitian ini bersifat spesifik sehingga menjadikan kewirausahaan etnik China lulusan SMK sangat menonjol. Di antaranya ternyata bahwa kewirausahaan terbentuk melalui proses yang dimulai dari sejak masih kanak-kanak dalam kehidupan keluarga.

Dari latar belakang kehidupan setiap keluarga etnik China lulusan SMK Singkawang masingmasing memiliki usaha yang dikelola secara bersama. Ayah sebagai pemimpin keluarga memimpin usaha dibantu oleh isteri dan anakanaknya tanpa kecuali yang masih kanak-kanak sesuai dengan kemampuan dan usianya.

Anak laki-laki menurut para informan memiliki tanggung jawab moral yang lebih karena sebagai penerus shiang atau marga dan pemujaan kepada leluhurnya. Karena sejak kecil dalam lingkungan keluarga mereka telah dibiasakan bekerja dan berusaha dalam bisnis keluarga, dengan demikian terbentuk kebiasaan berwirausaha sejak kecil. Semua anggota keluarga ikut bertanggung jawab sejak usia dini terhadap bisnis yang ditangani keluarga dan merupakan budaya turun temurun dan tetap dipertahankan hingga dewasa.

Keterlibatan anak dalam bisnis keluarga sejak kanak-kanak telah berhasil membentuk kebiasaan (habit-forming) bagi kehidupan usaha yang akan datang. Sejak Sekolah Dasar anak sudah biasa sekolah sambil bekerja mencari nafkah membantu orang tua. Sikap kewirausahaan makin terbentuk setelah mengikuti pendidikan di SMK karena di SMK diberikan pengetahuan, keterampilan dan pembentukan sikap agar mampu berwirausaha. Berwirausaha dengan sebenarnya baru dimulai setelah tamat dari sekolah dengan didahului berbagai diversifikasi usaha yang berbeda ragam dan fase perkembangannya tergantung dari usaha, keberuntungan atau hokki masing-masing.

Pembentukan kewirausahaan etnik China lulusan SMK merupakan proses didahului dengan proses pembentukan kebiasaan (habit-forming) dalam kehidupan keluarga. Proses berikutnya bekerja di luar rumah, bekerja dengan orang lain atau bekerja sendiri sambil sekolah di SMK, fase ini disebut fase Formatif (formative). Sesudah tamat dari SMK calon wirausahawan mencoba berusaha atau ikut dalam usaha orang lain untuk mandiri, fase ini disebut fase embrionik (embryonic). Dengan melalui berbagai tantangan dan diversifikasi usaha akhirnya wirausahawan dapat mandiri, ini merupakan fase produktif (productive) hingga akhirnya mencapai tingkat kematangan (maturation)

\section{Saran}

Beberapa saran yang diajukan ber-dasarkan hasil penelitian evaluasi ini dapat dikemukakan sebagai berikut.

Pertama, dari hasil penilaian tentang karakteristik kewirausahaan diperoleh analisis data yang objektif dalam penelitian bahwa etnik China lulusan SMK di kota Singkawang memiliki karakteristik kewirausahaan yang sangat mendukung dalam berwirausaha. Agar pola pembinaan kewirausahaan ini dapat dikembangkan pada siswa SMK lainnya. Dinas Pendidikan Kota Singkawang agar menghimbau para lulusan SMP lebih memilih melanjutkan ke SMK, Untuk memotivasi agar lulusan SMP memilih SMK dengan menyediakan dana beasiswa. Pemerintah daerah Kota Singkawang agar 
berpartisipasi dalam membina kewirausahaan dengan menyediakan modal belajar usaha bagi lulusan SMK yang memenuhi persyaratan.

Kedua, disarankan agar faktor yang dapat berpengaruh terhadap kewirausahaan baik yang bersifat internal maupun eksternal dapat dikondisikan untuk mendukung keberhasilan dalam berwirausaha. Faktor internal meliputi keyakinan, kepercayaan, agama dan kebudayaan. Faktor yang berpengaruh tersebut semua dapat bersinergi mendukung keberhasilan wirausahawan etnik China lulusan SMK Singkawang. Bahkan kesulitan, keterbatasan, dan kemiskinan yang berpotensi negatif pun dapat mendukung keberhasilan wirausaha.
Ketiga, dari hasil studi ternyata peran pendidikan SMK di Singkawang telah mampu mengembangkan pendidikan kewirausahaan yang mengakar pada kemampuan siswa. Pada pelaksanaan selanjutnya hendaknya siswa diberi kesempatan untuk mengelola program, mengelola keuangan dan kegiatan teknis yang lain dengan bimbingan guru. Siswa SMK Singkawang dari etnik China tidak mengalami kesulitan menyesuaikan.

Keempat, dalam rangka menindak lanjuti hasil dari studi ini disarankan kepada penentu kebijakan di bidang pendidikan agar dapat memprioritaskan program kewirausahaan melalui pendidikan anak, mulai usia dini di lingkungan keluarga. Dengan demikian, hendaknya sejak kanak-kanak dalam kehidupan keluarga sudah dibiasakan untuk berwirausaha.

\section{Pustaka Acuan}

Djaali, Pudji Mulyono dan Ramli. 2000. Pengukuran Dalam Bidang Pendidikan, Jakarta: PPS Universitas Negeri Jakarta.

Geoffrey. G. Meredith, Robert E Nelson, Philip A Neck. 1996. Kewirausahaan Teori dan Praktek, Jakarta: Pustaka Binaman Pressindo.

Gronlund E. Norman. 1985. Measurement and Evaluation in Teaching, London: Mc Milan, Collier Publishers.

HAR Tilaar. 2002. Tenaga Kependidikan di Tengah Perubahan Masyarakat, Jakarta: Grasindo \& Centre Of Education \& Community Development Studies.

Instruksi Presiden Republik Indonesia Nomor 14, Tahun 1967 tentang pengaturan bagi warga negara Indonesia keturunan China melakukan/menyelenggarakan kegiatan pesta kegiatan keagamaan dan kegiatan lain yang sejenis secara terbuka.

Keputusan Panglima Kodam XII Tanjungpura selaku Pelaksana Kopkamtib Daerah Kalimantan Barat tertanggal 25 Desember 1971 Nomor231/KAMDA/XII/1971 Tentang Pembaharuan di Bidang Pendidikan.

Koentjaraningrat. 1986. Kebudayaan Mentalitas dan Pembangunan, Jakarta: Gramedia.

Lontaan. 1975. Sejarah Hukum Adat dan Adat Istiadat Jakarta: Bumi Restu.

Masngudi. 1998. Kewirausahaan dan Strategi Usaha, Makalah disampaikan dalam seminar Kewirausahaan. Jakarta: Universitas Borobudur

Miles B. Matthew, Huberman Michael A. 1992. Qulitative Data Analysis, Jakarta Penerbit Universitas Indonesia.

Prihatin Benedicta. 2003. Kewirausahaan Dari Sudut Pandang Psikologi Kepribadian, Jakarta: PT. Grasindo.

Simanjuntak J. Payaman. 2005. Manajemen dan Evaluasi Kinerja, Jakarta: Lembaga Penerbit Fakultas Ekonomi Universitas Indonesia,

Suparno Suhaenah. A. 2002. Membangun Kompetensi Belajar, Jakarta: Ditjen Dikti Depdinas.

Soemanto Wasti. 1984. Pendidikan Wiraswasta, Malang: Penerbit Bumi Aksara.,

Wagiran K. Badrun. 1995. Pengertian dan Prinsip - Prinsip Evaluasi Program, Disampaikan sebagai materi penataran metodologi evaluasi program dalam rangka peningkatan kualitas peneliti dilembaga penelitian IKIP Yogyakarta,

Zakiah Darajat. 1991. Perawatan Jiwa Anak-anak, Jakarta: Bulan Bintang. 